\title{
The Fourth Circuit Court of Appeals' decision in United States $v$. Hurwitz: An important victory for pain management professionals and those living with pain
}

\author{
Jennifer Bolen, JD
}

\section{INTRODUCTION}

The federal court system has a way of leveling the playing field between the government and defendants, and it often does so in ways that benefit nondefendant stakeholders whose interests are affected by the cases processed by the system. ${ }^{1}$ On August 22, 2006, the United States Court of Appeals for the Fourth Circuit, ${ }^{2}$ at Alexandria, Virginia, leveled the playing field between the government and defendant William Eliot Hurwitz, $\mathrm{MD}$, and in doing so opened the door for pain management professionals to reclaim their right to establish generally accepted standards of care and to grow a body of experts who are willing to monitor the application of these standards, in both civil and criminal cases, by refusing to allow medical practice to be dictated merely by arbitrary numbers and combinations of drugs and by providing accurate and complete testimony in the courtroom. The future of pain management in the courtroom rests, in part, on the shoulders of this body of experts and their willingness to stand up to the government ${ }^{3}$ and its so-called experts, who jeopardize the interests of both pain management professionals and the patients they serve by giving testimony that falls short of expert standards. ${ }^{4}$ These experts will also have to navigate the final policy statement on dispensing controlled substances to treat pain, recently released by the Drug Enforcement Administration (DEA). ${ }^{5}$ You can read a short summary of the recently released DEA materials in Table 1.

\section{HURWITZ}

\section{General case background}

In December 2004, after a lengthy trial, a federal jury convicted Hurwitz of one count of drug trafficking conspiracy (21 USC $₫ 846$ ), one count of drug trafficking resulting in death, two counts of drug trafficking resulting in serious bodily injury, and 46 counts of drug trafficking (21 USC $₫ 841(\mathrm{a})(1))$. The jury acquitted Hurwitz of six counts of drug trafficking, one count of engaging in a continuing criminal enterprise, and two counts of healthcare fraud. The jury failed to reach a decision on the remaining drug trafficking counts. The trial court sentenced Hurwitz to 25 years' imprisonment.

Hurwitz appealed his conviction, arguing that the trial court improperly admitted evidence recovered in a search of his office and incorrectly instructed the jury on the law by failing to give the jury an instruction on "good faith" relating to the drug trafficking charges. ${ }^{6}$

\section{The Fourth Circuit Court of Appeals' decision: General explanation}

The Fourth Circuit affirmed (agreed with) the trial court's decision on the search warrant issue, meaning the Fourth Circuit found the law supported the trial court's decision to admit the search warrant as evidence at trial. But the Fourth Circuit disagreed with the trial court's decision on the jury instruction issue, so it vacated ${ }^{7}$ Hurwitz's conviction and remanded the case back to the district court for a new trial.

The Fourth Circuit based its decision in Hurwitz on a legal issue rather than on the facts of the case. The Fourth Circuit framed the deciding legal issue as follows:

[W] hether the trial court committed "reversible error" when it refused Dr. Hurwitz's request to give the jury an instruction on the subject of whether Dr. Hurwitz acted in "good faith" - that is according to generally accepted standards of care-as applied to the jury's examination of the facts relating to each of the drug trafficking charges against him.

The Fourth Circuit held that the trial court did indeed make a legal mistake by refusing to give the jury an instruction on good faith and based its decision to reverse Dr. Hurwitz's conviction and remand the case for a new trial on this point of law. The Fourth Circuit did not consider 


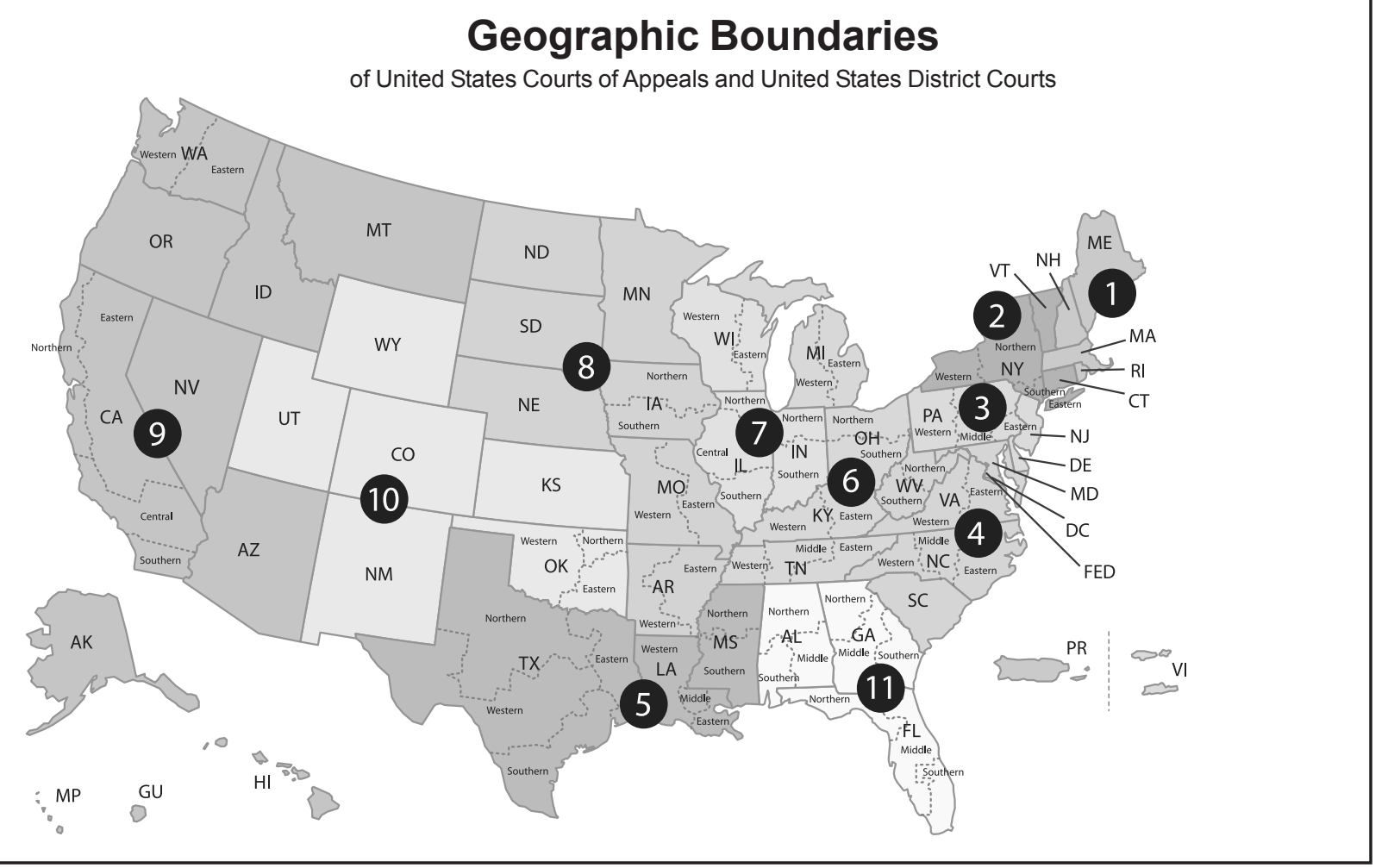

Figure 1. United States court districts.

whether the evidence against Dr. Hurwitz was sufficient as a matter of law. ${ }^{8}$

The Fourth Circuit's opinion in Hurwitz presents an opportunity for the pain management community to regain some ground and focus on the importance of accurate expert testimony. I believe the Hurwitz opinion may also help the pain management community direct the government's attention to other stakeholders, like healthcare plans, ${ }^{9}$ who share responsibility for minimizing the potential for abuse and diversion of controlled substances while still ensuring that these medications remain available for people who have a legitimate medical need for them.

\section{ELEMENTS OF A SECTION 841 OFFENSE}

Federal law permits doctors who are "registered" by the Attorney General to write prescriptions for or to otherwise dispense controlled substances as long as they comply with the requirements of their registration. ${ }^{10}$ The Code of Federal Regulations contains regulations addressing "the conditions under which registrants are authorized to dispense controlled substances." For example, 21 CFR $\$ 1306.04$ (a) (2006) provides that a prescription for a controlled substance is effective only if it is "issued for a legitimate medical purpose by an individual practitioner acting in the usual course of his professional practice." This regulation further provides that "an order purporting to be a prescription issued not in the usual course of professional treatment or in legitimate and authorized research is not a valid prescription within the meaning and intent of [the Controlled Substances Act] and the person knowingly . . . issuing [such a purported prescription] shall be subject to the penalties provided for violations of the provisions of law relating to controlled substances." 11

Against this background, then, the government can bring a federal criminal case against a physician for "drug trafficking" under Title 21, United States Code, Section 841(a)(1), which makes it unlawful for "any person knowingly or intentionally ... to . . distribute, or dispense, or possess with intent to . . distribute, or dispense, a controlled substance." 12 To convict a physician of a drug trafficking crime under Section 841(a)(1), the government must prove each of the elements listed on the left side of Table 2 beyond a reasonable doubt.

Hurwitz argued that the trial court's failure to give an instruction on good faith deprived him of the ability to argue against the intent, or mens rea, element of a Section 841(a)(1) offense, which asserts that the defendant acted "knowingly and intentionally." Thus, the right side of Table 2 shows the application of the Section 841 elements to Hurwitz's arguments on appeal and demonstrates how important the good faith jury instruction is to negating (or potentially negating) the government's argument that 
Table 1. Publications released by the DEA on September 6, 2006

\begin{tabular}{|c|c|}
\hline Item released & Key concepts \\
\hline $\begin{array}{l}\text { Updated DEA Practitioners Manual } \\
\text { (www.deadiversion.usdoj.gov/pubs/manuals/pract/ } \\
\text { pract_manual090506.pdf) }\end{array}$ & $\begin{array}{l}\text { This is an update from the DEA's } 1990 \text { Practitioner's Manual. It } \\
\text { contains a short summary of key registrant obligations under } \\
\text { the Controlled Substances Act; good reference material. }\end{array}$ \\
\hline $\begin{array}{l}\text { Final Policy Statement on Dispensing Controlled Substances for } \\
\text { the Treatment of Pain (www.deadiversion.usdoj.gov/ } \\
\text { fed_regs/notices/2006/fro9062.htm) }\end{array}$ & $\begin{array}{l}\text { This is the DEA's final statement on two earlier items, the } \\
\text { Interim Policy Statement (issued November 2004) and the } \\
\text { Clarification Statement (issued August 2005). It is also a com- } \\
\text { promise for the published and retracted document known as } \\
\text { Prescription Pain Medications: Frequently Asked Questions and } \\
\text { Answers. This is a MUST READ. }\end{array}$ \\
\hline $\begin{array}{l}\text { Notice of Proposed Rule-Making on the Use of Multiple } \\
\text { Schedule II Prescriptions (www.deadiversion.usdoj.gov/ } \\
\text { fed_regs/rules/2006/fro906.htm) }\end{array}$ & $\begin{array}{l}\text { Concerns the so-called "Do Not Fill" prescriptions. The DEA } \\
\text { has decided that the use of multiple Schedule II prescriptions, } \\
\text { under certain circumstances, is proper and may help a physi- } \\
\text { cian minimize the potential for abuse and diversion. This rule is } \\
\text { only proposed and will become final after the public comment } \\
\text { period and other legal notification periods take place. }\end{array}$ \\
\hline $\begin{array}{l}\text { Cases Against Doctors } \\
\text { (www.deadiversion.usdoj.gov/crim_admin_actions/index.html) }\end{array}$ & $\begin{array}{l}\text { The DEA has summarized both administrative and criminal } \\
\text { actions against physicians over the past few years. This refer- } \\
\text { ence contains illustrative examples of cases where the DEA } \\
\text { used its investigative authority to pursue a physician because } \\
\text { of his/her prescribing activity. }\end{array}$ \\
\hline ote & in \\
\hline
\end{tabular}

Hurwitz acted knowingly or intentionally. The harm done by the trial court's failure to give the good faith instruction is obvious: if the jury should have been instructed to consider whether Hurwitz acted in good faith, then one or more of the jurors may have believed that he acted in good faith instead of knowingly or intentionally and thus may have voted differently on the Section 841 charges. ${ }^{13}$ Since the trial court never gave the Hurwitz jury this opportunity, the Fourth Circuit held that such a failure constituted legal error which could only be cured by reversing the conviction and sending the case back for another trial. ${ }^{14}$ The Fourth Circuit's decision means even more to the pain management community as a whole.

The Fourth Circuit made the following additional observations about the application of the good faith standard to drug trafficking charges against physicians:

1. "[A] doctor's good faith generally is relevant to a jury's determination of whether the doctor acted outside the bounds of medical practice or with a legitimate medical purpose when prescribing narcotics."

\section{Referring to United States $v$. Moore, 423 US 122} (1975), a doctor could not be convicted if he merely made "'an honest effort' to prescribe . . . in compliance with an accepted standard of medical practice."16

3. "When resolving the ultimate question in a Section 841 prosecution against a doctorwhether the doctor acted without a legitimate medical purpose or beyond the bounds of accepted medical practice-some latitude must be given to doctors trying to determine the current boundaries of acceptable medical practice."

4. Courts have consistently concluded that it is proper to instruct juries that a doctor should not be held criminally liable if the doctor acted in good faith when treating his patients, citing cases from the Second, Fifth, Sixth, and Ninth Circuits. ${ }^{17}$

\section{SUBJECTIVE VERSUS OBJECTIVE GOOD FAITH STANDARDS}

The Fourth Circuit held that the trial court erred by concluding that good faith is not relevant when a registered physician is charged with violating Section 841 and stated that an objective good faith standard applies in the prosecution of Section 841 drug trafficking cases against physicians. The Fourth Circuit carefully distinguished and rejected the use of a subjective good faith standard (as 
Table 2. Elements of a Section 841 offense ${ }^{15}$

\begin{tabular}{|l|l|}
\hline & Application to Hurwitz's case \\
\hline The defendant & Hurwitz \\
\hline Knowingly and intentionally & This is where the jury instruction was key \\
\hline Distributed or dispensed & Includes writing prescriptions \\
\hline A controlled substance & Various proven at trial in various schedules \\
\hline $\begin{array}{l}\text { In a manner that demonstrates his actions were not for legitimate medical } \\
\text { purposes in the usual course of professional practice }{ }^{12} \text { OR }\end{array}$ & $\begin{array}{l}\text { This is where the expert witness and factual } \\
\text { testimony are key to the retrial }\end{array}$ \\
\hline In a manner that was beyond the bounds of medical practice & $\begin{array}{l}12 \\
\text { This is where the expert witness and factual }\end{array}$ \\
\hline
\end{tabular}

requested by Hurwitz), stating that the phrase "professional practice" refers to "generally accepted medical practice," and "a practitioner is not free deliberately to disregard prevailing standards of treatment . ..."18 In this regard, the Fourth Circuit reasoned that "to permit a practitioner to substitute his or her views of what is good medical practice for standards generally recognized and accepted in the United States would be to weaken the enforcement of our drug laws in a critical area."19

\section{APPLICABILITY OF THE GOOD FAITH ISSUE TO EXPERT TESTIMONY}

Much of Hurwitz involved a "battle of the experts," and many medical professionals have commented on the substance of the expert testimony and the negative impact (intended or not) of the government medical expert's testimony on the pain management community as a whole. ${ }^{20}$ Fortunately, the Fourth Circuit's opinion in Hurwitz softens the potential harm of that testimony and offers an opportunity for medical experts to correctly address these issues in the future, at the retrial and certainly in future cases where the government medical expert opts to take the same position or is available for cross-examination.

The Fourth Circuit's decision in Hurwitz opens the door for the pain management community and Hurwitz's trial team to go back and prepare to completely discredit the government medical expert's claim concerning the existence and nature of a daily ceiling dose of opioids and to revisit incredibly important medical issues such as treating pain in addicts (or those with a history of addiction or who exhibit aberrant drug-related behaviors) and the concepts of physical dependence and tolerance.

Table 3. Importance of the good faith instruction

\begin{tabular}{|c|c|c|}
\hline District court action at trial & Hurwitz's objections & Appellate court's position \\
\hline $\begin{array}{l}\text { The district court refused to } \\
\text { issue Hurwitz's good faith } \\
\text { instruction. }\end{array}$ & $\begin{array}{l}\text { Hurwitz believed the court } \\
\text { should have given the good } \\
\text { faith instruction he drafted. }\end{array}$ & $\begin{array}{l}\text { Hurwitz's instruction WAS NOT PROPERLY WORDED, and } \\
\text { thus the district court rightfully rejected the instruction. }\end{array}$ \\
\hline $\begin{array}{l}\text { The district court refused to } \\
\text { give any good faith instruction } \\
\text { relating to the drug trafficking } \\
\text { charges. }\end{array}$ & $\begin{array}{l}\text { Hurwitz believed the court } \\
\text { should have given some form } \\
\text { of a good faith instruction relat- } \\
\text { ing to the drug trafficking } \\
\text { charges. }\end{array}$ & $\begin{array}{l}\text { The court agrees with Hurwitz and believes the district court } \\
\text { confused the rejection of Hurwitz's improperly worded good } \\
\text { faith instruction with its decision not to issue any good faith } \\
\text { instruction to the jury related to the drug trafficking charges. } \\
\text { This constituted reversible error because a reasonable juror } \\
\text { could have found that Hurwitz's actions were in good faith. } \\
\text { Thus, the appellate court decided to vacate (or take away) } \\
\text { Hurwitz's conviction and remand (send back) the case to the } \\
\text { district court for a new trial. }\end{array}$ \\
\hline
\end{tabular}


Those who contributed to the "friends of the court" briefs in the Hurwitz case are largely responsible for focusing the Fourth Circuit on the good faith standard's importance to the pain management community as a whole. The Fourth Circuit has done its job, and now it is up to the leaders in the pain management community to consider its accepted standards of care and what they mean to prescribers and patients alike, so that good faith remains a strong shield against any government attempt (through its agents or hired experts) to dictate how much of what drug it thinks I or any other patient who lives with chronic pain should take or what our physicians can prescribe to us.

Jennifer Bolen, JD, The J. Bolen Group, LLC, Knoxville, Tennessee.

\section{NOTES AND REFERENCES}

1. Several groups or stakeholders filed amicus curiae ("friends of the court") briefs with the Fourth Circuit. The American Academy of Pain Medicine filed such a brief in an effort to set forth the interests of its members. I believe this brief, and others, had a large impact on the Fourth Circuit's decision in this case and certainly helped the appellate court understand the larger interests at stake. This is significant because of the nature of the expert witness testimony during the Hurwitz trial and its potential impact on the pain management community as a whole.

2. Federal appellate courts are referred to by circuit number. For example, the Fourth Circuit Court of Appeals covers multiple states, and the federal district courts within each of those states feed into the Fourth Circuit according to federal law and the rules of appellate procedure. By example, the State of Virginia has two federal districts-Eastern and Western-and a defendant's appeal of a jury trial conviction in either of those districts goes to the Fourth Circuit Court of Appeals. The basic order of the federal criminal court system is 1) district court (trial), 2) court of appeals (appeal), and 3) US Supreme Court (assuming there is a prerequisite for Supreme Court jurisdiction). If you want more information on the specifics of the federal court system, see www.uscourts.gov.

3. The government is not the only source of problem expert testimony in this area. There are many examples of civil cases against pharmaceutical companies and physicians brought by plaintiffs' attorneys whereby medical experts support lawsuits founded on "you got me addicted" or "you caused my daughter/son to overdose and die" allegations. Any party or expert putting forward allegations that lack the support of generally accepted standards of care jeopardizes the pain management community.

4. This may also be stated as expert testimony that fails to recognize the lack of literature on a specific issue when the issue has not been studied or has only recently been identified or that fails to recognize the many approaches to pain management and the varied state laws and regulations on the use of controlled substances to treat pain.

5. Released September 6, 2006, and available at www.dea diversion.usdoj.gov or through links set up on my Web site at www.legalsideofpain.com.

6. Hurwitz, 2006 US App. LEXIS 21425 (August 22, 2006).

7. When a sentence is vacated, it means that it is set aside.
However, in this case this is a temporary situation, because the Fourth Circuit also sent the case back to the district court for a new trial with instructions that the trial judge follow the law regarding the use of the proper jury instructions. The government is very likely to retry this case, unless Hurwitz can convince the government that it will have big problems during the retrial with expert testimony, the concept of good faith, and the pain management community's current accepted standards of care on the use of high-dose opioid therapy. The government can use its old charges against Hurwitz in the second trial, or it can use a "superseding indictment" and proceed against Hurwitz in a slightly different manner. The government's decision will likely be based on how it views its expert testimony at this point, and given all the potential points of attack that this expert or one like him will face, the government's decision will be more difficult the second time around, especially now that it must operate under the law that it knew existed from the very beginning: the objective good faith standard.

8. The Fourth Circuit acknowledged that the more challenging issue is the government's claim that the trial evidence so "overwhelmingly demonstrated that Hurwitz was acting well beyond the bounds of accepted medical practice that the jury could not reasonably have found that he acted in good faith." In rejecting the government's claim, the Fourth Circuit said that "while the government's evidence [in Hurwitz] was powerful and strongly indicative of a doctor acting outside the bounds of accepted medical practice, we cannot say that no reasonable juror could have concluded that Hurwitz's conduct fell within an objectively-defined good-faith standard." Significantly, the Fourth Circuit pointed out that Hurwitz presented expert testimony showing that it was proper to use opioids when treating addicts who suffered from pain, that Hurwitz's high-dose opioid therapy was a medically appropriate way to treat intractable pain, and that the quantities of opioids he prescribed were appropriate. "Even as to the patients whose dosages appeared extraordinarily high, such as the patient who was prescribed over 500,000 pills during the course of his treatment, the record contains expert testimony showing that Hurwitz's treatment and the quantities of opioids prescribed was medically proper." The Fourth Circuit cited other evidence at trial supporting Hurwitz's position on the good faith jury instruction, including Hurwitz's testimony about his own practice, his use of medical history questionnaires, discussions with other physicians outside his practice about accepted procedures, and Hurwitz's reliance on information obtained at professional medical conferences.

The Fourth Circuit believed the trial court effectively deprived the Hurwitz jury of the opportunity to consider Hurwitz's defense. Although it recognized that the government's evidence against Hurwitz "was strong," the Fourth Circuit said it could not "conclude that the district court's error in removing the good faith from the jury's consideration was harmless." Thus, it concluded that good faith is relevant to Section 841 charges against a registered physician and that the trial court erred by incorrectly instructing the jury that Hurwitz's good faith was relevant only to the healthcare fraud charges. On remand, the Fourth Circuit specifically told the district court to include a good faith instruction using an objective standard (if requested by Hurwitz and if supported by the evidence presented at retrial).

9. Health plan providers may be one of the largest stakeholder groups and continue to make decisions that, in many ways, impede physicians' ability to both comply with the laws and regulations on controlled substance prescribing and care for patients according to generally accepted standards of care in the pain management community, especially regarding the long-term use of controlled substances to treat pain alone or in 
special patient populations.

10. See 21 USC $₫ 822(\mathrm{~b})$

11. 21 CFR 1306.04(a)(2006).

12. 21 USC 841(a)(1).

13. The same argument would apply to the Section 846 charge of conspiracy because the elements are essentially the same.

14. At trial, the district court did give a good faith instruction to the jury on the two healthcare fraud charges against Hurwitz and told the jury that "it could not convict Dr. Hurwitz if he 'acted in good faith in dispensing any of the prescriptions alleged to constitute the crime of healthcare fraud." However, the trial court also told the jury that "good faith applies only" to the healthcare fraud counts, and "not only declined to give a good-faith instruction with regard to the drug counts, but also informed the jury that it could not consider good faith when deciding whether to convict Hurwitz of drug trafficking under Section 841." The Fourth Circuit held that the trial court's actions further supported its decision to reverse the case because of legal error.

15. United States v. Singh, 54 F.3d 1182, 1187 (4 $4^{\text {th }}$ Cir. 1995); see also Alerre, 430 F.3d at 689-690; United States v. Daniel, 3 F.3d 775, 778 ( $4^{\text {th }}$ Cir. 1993); United States $v$. Tran Trong Cuong, 18 F.3d 1132 , 1141 ( $4^{\text {th }}$ Cir. 1994). Note: according to the Hurwitz court, the issue of whether the defendant's actions were for legitimate medical purposes or were beyond the bounds of medical practice is not an essential element of a $\$ 841$ charge against a doctor (see United States v. Steele, 147 F.3d 1316, 1318 [11 ${ }^{\text {th }}$ Cir. 1998] [en banc]; United States v. Polan, 970 F.2d 1280, 1282 [ $3^{\text {rd }}$ Cir. 1992]; United States $v$. Seelig, 622 F.2d 207, 211-212 [6 ${ }^{\text {th }}$ Cir. 1980]).

16. Moore, 423 US at 142 n.20.

17. Here are the cases cited by the Fourth Circuit in Hurwitz: Alerre, 430 F.3d at 692 (noting that "the jury was correctly instructed on the applicable legal principles," and that the jury was instructed that the defendant-doctors "could not be convicted if they had dispensed the controlled substances at issue 'in good faith'"); United States v. Hughes, 895 F.2d 1135, 11411142 ( $6^{\text {th }}$ Cir. 1990) (citing Moore's standard that physicians can not be convicted if they "dispens[e] controlled substances in the course of professional practice" and explaining that "[b]ecause Dudley was a licensed physician, the jury could not find him guilty of distributing controlled substances, as long as he acted in 'good faith"'); United States v. Vamos, 797 F.2d 1146, 1151 ( $2^{\text {nd }}$ Cir. 1986) ("[T]he doctor must act in the good faith belief that his distribution of the controlled substance is for a legitimate medical purpose and in accordance with the usual course of generally accepted medical practice"); United States $v$. Hayes, 794 F.2d 1348, 1351-1352 (9 $9^{\text {th }}$ Cir. 1986) (finding no error in the charge that required the jury to determine that the physician acted other than in good faith and defined good faith as "an honest effort to prescribe for a patient's condition in accordance with the standard of medical practice generally recognized and accepted in the country"); United States v. Norris, 780 F.2d 1207 , 1209 n.2 ( $5^{\text {th }}$ Cir. 1986) (finding proper the district court's instruction to the jury that "[a] controlled substance is prescribed by a physician in the usual course of a professional practice, and, therefore, lawfully, if the substance is prescribed by him in good faith, medically treating a patient in accordance with a standard of medical practice generally recognized and accepted in the United States"); United States v. Carroll, 518 F.2d 187,189 ( $6^{\text {th }}$ Cir. 1975) (reversing conviction because the trial court "did not advise [the jury] that physicians are exempt from the provisions of the drug abuse statute when they dispense or prescribe controlled substances in good faith to patients in the regular course of professional practice").

18. Hurwitz, 2006 US App. LEXIS 21425 (August 22, 2006), quoting Vamos, 797 F.2d at 1151, 1153; see also United States $v$ Williams, 445 F.3d 1302, 1309 (11 ${ }^{\text {th }}$ Cir. 2006) ("Williams's proposed instruction fails to introduce any objective standard by which a physician's prescribing behavior can be judged. Under Williams's proposed instruction, if it is a physician's subjective belief that he is meeting a patient's medical needs by prescribing that patient a controlled substance, then that physician cannot be convicted of violating the Controlled Substances Act even if he acts outside all accepted standards of medical practice. Thus, the proposed instruction is contrary to Moore."); Norris, 780 F.2d at 1209 (rejecting defendant's claim "that a standard medical practice may be based on an entirely subjective standard" because "[o]ne person's treatment methods do not alone constitute a medical practice"); 3 Leonard B. Sand et al., Modern Federal Jury Instructions, Instruction 56-19, comment (2003) ("Every court to examine the issue has held that the objective standard that the doctor acted in accordance with what he reasonably believed to be proper medical practice should apply.”).

19. See references in the note above. This argument can easily be applied to government experts who substitute their own views of what is good medical practice for standards generally recognized and accepted in the United States, which would weaken pain management; see note 20 below and related text.

20. Specifically, the government hired Michael Ashburn, MD, as its medical expert. Ashburn testified that it was his expert opinion that the daily ceiling dose of opioids is $195 \mathrm{mg}$ morphine equivalent and that physicians are limited by law to prescribing a 30-day supply of any Schedule II controlled substance. Medical experts testifying on Dr. Hurwitz's behalf and those who wrote the trial judge during the sentencing phase of Hurwitz's case took a strong stance against Ashburn's position, stating that it did not accurately reflect generally accepted standards of care among pain professionals. My purpose in pointing this out is not to "pick on" Dr. Ashburn but to illustrate the damage that can be done when one testifies without doing so according to generally accepted standards of care or the good faith standard discussed by the Fourth Circuit in the Hurwitz opinion. A careful reading of Dr. Ashburn's testimony before the jury reveals he sometimes used a subjective standard of care in pain management or even a specific rule of law applicable to physicians in Utah (where Dr. Ashburn practiced) but not in Virginia (where Dr. Hurwitz practiced), referring to the 30-day limit on a Schedule II controlled substance prescription. This is significant because testimony like this has the ability to mislead a jury into thinking that such a limit applies nationwide (whether a daily or monthly dosage limit). The DEA has recently stated that every patient's case is different, and state laws on this issue vary. Better yet, the DEA has acknowledged-and the Hurwitz prosecutors should have known - that the federal law does not have a monthly dosage quantity limit when it comes to Schedule II medications. Because of the Fourth Circuit's decision, the pain management community is in a better position to stand up to government medical experts who take positions contrary to generally accepted standards of care in their field and to set the record straight so that in future cases their prescribing rights are not jeopardized. 